\title{
Area-intensive bottom culture of blue mussels Mytilus edulis in a micro-tidal estuary
}

\author{
Per Dolmer ${ }^{1, *}$, Helle Torp Christensen ${ }^{1}$, Benni Winding Hansen ${ }^{2}$, Bent Vismann ${ }^{3}$ \\ ${ }^{1}$ Technical University of Denmark, National Institute of Aquatic Resources, Jægersborg Allé 1, 2920 Charlottenlund, \\ Denmark \\ ${ }^{2}$ Roskilde University, Department of Environmental, Social and Spatial Change, Universitetsvej 1, PO Box 260, 4000 Roskilde, \\ Denmark \\ ${ }^{3}$ University of Copenhagen, Department of Biology, Marine Biological Section, Strandpromenaden 5, 3000 Helsingør, \\ Denmark
}

\begin{abstract}
Dredge fishery for blue mussels Mytilus edulis (L.) impacts the benthic ecosystem, and substitution by area-intensive bottom culture production may reduce adverse effects on the ecosystem. Two different field studies in 2007 and 2009 tested the productivity of bottom culture of blue mussels, and whether a shift from dredging of full-grown blue mussels to production of blue mussels in bottom culture could reduce the area of impacted sea bottom. In the first study, the macrostructure of a commercial bottom culture was analysed by side scan mapping, and the growth of blue mussels was recorded on a transect from the edge to the central part of the bottom culture. In the second study, we analysed the effect of seeding density $\left(1.5\right.$ and $\left.3.5 \mathrm{~kg} \mathrm{~m}^{-2}\right)$ on mussel production. The measured production was used to model the affected area when producing blue mussels in bottom culture. The macrostructure of the culture bed formed during the transplantation of mussel seed was not changed $1 \mathrm{yr}$ after transplantation, indicating that transplantation supported the formation of a robust blue mussel bed. Shell growth showed no spatial variability from the edge to the central part of the commercial bottom culture, suggesting that growth was not reduced by density-dependent food limitation. The population production:biomass ratio $(P / B)$ of the experimental bottom cultures was 1.0 and showed no significant effect of seeding density. Model simulations indicated that the impacted area was smaller when producing blue mussels in bottom culture than in a fishery of full-grown mussels if $P / B$ was higher than 0.5 .
\end{abstract}

KEY WORDS: Bottom culture $\cdot$ Ecosystem impact $\cdot$ Production:biomass $\cdot$ Shell growth $\cdot$ Mytilus edulis $\cdot$ Blue mussels $\cdot$ Transplantation

\section{INTRODUCTION}

Europe has a long tradition of producing blue mussels Mytilus edulis (L.) in bottom culture (Smaal 2002, Gosling 2003). Traditionally, blue mussel seed for bottom culture is fished by dredge from natural mussel beds in areas with high production of seed. After collection, the seed is transplanted to bottom culture beds in areas supporting a high growth rate and a low mortality rate (Spencer 2002). In Denmark, the main part of the blue mussel production is based on dredging full-grown mussels in natural populations (Dolmer \& Frandsen 2002, Smaal 2002). Dredging is among the most harmful fishing methods for benthic ecosystems (Jennings \& Kaiser 1998, Collie et al. 2000, Kaiser et al. 2006). The dredging activities for mussels in subtidal areas may change marine ecosystems in relation to benthic organisms (Dolmer et al. 2001, Dolmer 2002, Neckles et al. 2005) and substrate (Dolmer 2002) and may induce cascade effects on higher trophic levels, including birds (Atkinson et al. 2010). 
Aquaculture is identified as a production form that meets the growing demand for shellfish, and extensive knowledge on the ecosystem impacts of aquaculture was established during the last decade (Cranford et al. 2007, Dumbauld et al. 2009, McKindsey et al. 2011). Production of blue mussels in bottom culture can change the structure of the ecosystem, thereby affecting several trophic levels (Dankers \& Zuidema 1995). Bottom culture may change the composition of the benthic community, with a decreased number of species and individuals (Beadman et al. 2004, Smith \& Shackley 2004). Positive effects have also been documented, including increased biodiversity due to biodeposition from filtering mussels and the trapping effect of the mussel bed changing the sedimentary environment due to the introduction of a complex mussel matrix that offers habitat for epibenthic organisms (Ysebaert et al. 2009). Furthermore, common eiders Somateria mollissima may benefit from an increased source of food in areas with bottom culture of blue mussels (Smaal et al. 2010). With reference to the implementation of Nature 2000, Marine Strategy Framework Directive (MSFD) and Water Framework Directive (WFD) legislations, there is a political request to adapt new, more sustainable production methods with reduced ecosystem impact. In contrast to traditional mussel dredging, the use of bottom culture as a production platform may reduce adverse effects on the ecosystem. Estimates of areas impacted by different production forms are thus a prerequisite for choosing appropriate management strategies.

Few studies have reported on the productivity of bottom cultures (e.g. Dankers 1987, Kristensen \& Lassen 1997, Kamermans \& Smaal 2002). In Limfjorden, Denmark, the productivity of transplanted blue mussels was shown to be 2 to 7 times higher than in natural blue mussel beds (Kristensen \& Lassen 1997). However, Yanick et al. (2003) showed that natural populations of Mytilus trossulus performed better than transplanted mussels on the east coast of Vancouver Island, Canada. Regardless of whether blue mussels are situated in natural or culture beds, they will affect downstream food availability within and above the mussel beds (Fréchette \& Bourget 1985a,b, Fréchette et al. 1989, Butman et al. 1994, Saurel et al. 2007), and continuous availability of food is one of the most important factors determining the growth of blue mussels (Seed 1976, Suchanek 1981). Hence, a balanced ratio between mussel abundance and food availability is necessary to ensure a high production and avoid growth limitation in the central part of a mussel bed (Okamura 1986, Svane \& Ompi 1993).
Production of mussels in bottom culture is based on transplantation of mussels from areas with high seed density to culture areas where density is reduced to improve production (Spencer 2002). Thus, bottom culture must be established using knowledge on the best design of beds, optimal seeding density and area characteristics to support a high production rate. Since growth is a key parameter for production, knowledge of the effects of the macrostructure of bottom culture, effects of individual mussel position in a bottom culture and effects of seeding density are crucial when planning production. Our aims were therefore to describe the macrostructure of a commercial bottom culture bed and to test blue mussel growth as a function of position in the bottom culture bed. Furthermore, in a field experiment, bottom cultures were created with different seeding densities to test the effects on production. The impacted area when producing mussels in bottom culture was analysed in model simulations as a function of production ratios and seeding densities.

\section{MATERIALS AND METHODS}

\section{Study area}

Field observations conducted in spring 2009 of macrostructure and shell growth on a commercial bottom culture bed of blue mussels and production experiments conducted in spring 2007 on bottom cultures with 2 different initial densities of seed were conducted in Kaas Broad (56 $46^{\circ}$ N, 08 $45^{\prime}$ E) in Limfjorden, Denmark, in 2 separate field studies (Fig. 1). Limfjorden is a $1575 \mathrm{~km}^{2}$ sound open to the North Sea in the west and to the Kattegat in the east. Salinity ranges from $32 \mathrm{psu}$ in the western part to $22 \mathrm{psu}$ in the eastern part and is controlled by the predominantly west to east current. Barometric forcing induces water exchange and circulation, whereas tidal pumping is insignificant because of its low amplitude (0.1-0.2 m; Dolmer 2000). The average water depth in Kaas Broad is approximately $6 \mathrm{~m}$. The mean chlorophyll a (chl a) concentrations for Kaas Broad during spring and summer were 8.5 and $5-9 \mathrm{mg} \mathrm{m}^{-3}$, respectively (Markager et al. 2006).

\section{Macrostructure of commercial bottom culture}

A commercial culture bed was mapped in April 2009 using side scan sonar (Humminbird 1197c SI Combo; Blondel 2009; Fig. 1B). The side scan map 

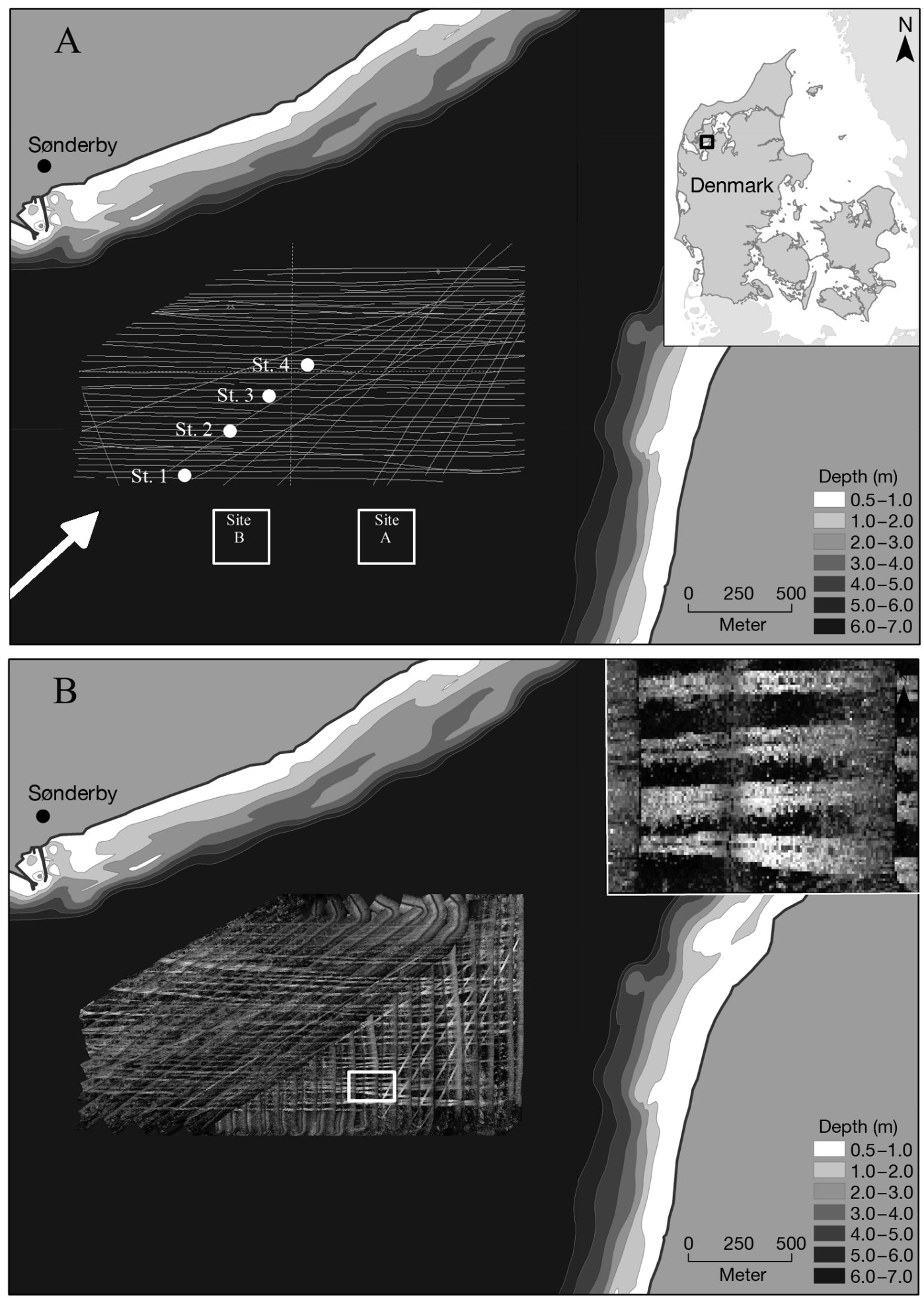

Fig. 1. Study area. (A) Original vessel GPS tracks generated during transplantation of blue mussels in 2008. White circles indicate the 4 sample stations on the commercial culture bed in 2009 (Stn 1: edge of culture bed; Stn 4: centre of culture bed; Stns 2 and 3: between the edge and centre stations). White boxes indicate experimental culture Sites A and B for the experiment conducted in 2007. The white arrow indicates the predominant direction of the water current. (B) Side scan map of the culture bed $1 \mathrm{yr}$ after transplantation (2009). White and light gray horizontal lines show hard substrate (i.e. live and dead mussels). The darker area between the white and light grey horizontal tracks is soft seabed. Magnification of 4 parallel transplantation tracks (white rectangle) is shown in top right corner 
was compared to the tracks registered from MS 'Limfjorden' during the transplantation (Fig. 1A). The commercial bottom culture bed $\left(56^{\circ} 40.3^{\prime} \mathrm{N}, 08^{\circ} 45.5^{\prime} \mathrm{E}\right)$ was established by the vessel MS 'Limfjorden' in April to June 2008. The blue mussel seed was transplanted in straight tracks with bare strips of 15 to $20 \mathrm{~m}$ in between. Mussel seed was pumped out from both sides of the vessel and settled at the bottom in 2 tracks of about $2 \mathrm{~m}$ in width and about $5 \mathrm{~m}$ apart (shown as white and light grey tracks in Fig. 1B). The mean shell lengths of the transplanted mussels $( \pm \mathrm{SD}$; $\mathrm{n}=150$ ) at Stns 1 to 4 are given in Table 1 . The seed was derived from natural blue mussel beds and was deposited at a biomass density of $3.5 \mathrm{~kg} \mathrm{~m}^{-2}$ across the entire culture bed (Fig. 1A).

\section{Growth in commercial bottom culture}

In order to describe mussel growth in commercial bottom culture, mussels were sampled at 4 stations along a transect ranging from southwest to northeast from the edge of the bed to the middle of the bed (Fig. 1A), since this is the dominant water current direction in Kaas Broad (Wiles et al. 2006). Stations were separated by approximately $300 \mathrm{~m}$.

At Stns 1 and 4, 20 frame samples $\left(0.25 \mathrm{~m}^{2}\right)$ of mussels were collected randomly by a SCUBA diver. At Stns 2 and 3, 10 samples were collected at each station. The total number of mussels in each sample was counted, and shell lengths were recorded using a digital calliper $(0.1 \mathrm{~mm})$. Stns 2 to 4 had 2 distinct size classes, while at Stn 1, only 1 broad size class was identified. The age of mussels was recorded from visual inspection of growth rings on the shells (Bayne 1976) at each station $(n=20)$. This indicated a mixed population of $2 \mathrm{yr}$ old transplanted and $1 \mathrm{yr}$ old settled mussels at all 4 stations. Assuming 2 cohorts, the statistics (mean shell length, SD and number of individuals) at each station were determined for each cohort. According to the cohort analysis, trans-

Table 1. Mytilus edulis. Mean \pm SD shell lengths $(\mathrm{mm})$ of blue mussel seed transplanted in 2008 and sampled from the commercial bottom culture in 2009. The percentage of mussels settled after transplantation, and the percentage of transplanted mussels is given for samples from 2009

\begin{tabular}{|c|c|c|c|c|c|c|c|c|}
\hline Mussels & $\begin{array}{r}\text { Stn } 1 \\
\text { Length }\end{array}$ & $\%$ & $\begin{array}{r}\text { Stn } 2 \\
\text { Length }\end{array}$ & $\%$ & $\begin{array}{r}\text { Stn } 3 \\
\text { Length }\end{array}$ & $\%$ & $\begin{array}{c}\text { Stn } 4 \\
\text { Length }\end{array}$ & $\%$ \\
\hline Transplanted - 2008 & $16 \pm 4$ & & $28 \pm 5$ & & $26 \pm 3$ & & $21 \pm 4$ & \\
\hline Settled - 2009 & $17 \pm 1$ & 12 & $24 \pm 2$ & 21 & $19 \pm 2$ & 45 & $19 \pm 2$ & 24 \\
\hline Transplanted - 2009 & $28 \pm 3$ & 88 & $41 \pm 1$ & 79 & $44 \pm 2$ & 55 & $35 \pm 4$ & 76 \\
\hline
\end{tabular}

planted mussels were defined as mussels larger than the mean initial shell length plus 1 SD. Mussels settled after transplantation were defined as mussels less than the mean initial shell length of transplanted mussels. Shell lengths and percentages of mussels in each cohort are given in Table 1.

Due to differences in initial shell lengths of transplanted blue mussels, the cohort of $1 \mathrm{yr}$ old mussels settled after the establishment of the bottom culture was used to test whether growth differed between the stations, assuming that settled mussels were settled synchronously. Growth of the 2 yr old transplanted mussels was measured in order to contrast production conditions at the study site to other production areas. The dry weight of tissue (DW) of sampled mussels was measured (Stn 1, n = 199; Stn 2, n = 123; $\operatorname{Stn} 3, \mathrm{n}=69 ; \operatorname{Stn} 4, \mathrm{n}=95$ ) at the 4 stations. The tissue was dissected out and dried for $24 \mathrm{~h}$ at $105^{\circ} \mathrm{C}$. Tissue samples were then left to cool in a desiccator for $30 \mathrm{~min}$ before the dry tissue weight $(\mathrm{g})$ was measured. The condition index (CI) was calculated for transplanted mussels at each station as: $\mathrm{CI}=\mathrm{DW} / L^{3}$, where $\mathrm{DW}$ is the dry weight of tissue $(\mathrm{mg})$ and $L$ is shell length $(\mathrm{cm})$ (Lucas \& Beninger 1985, Petersen et al. 2004), as the measured difference in initial shell length will not affect CI (Riisgård et al. 2012).

\section{Production as a function of seeding density in experimental bottom cultures}

Two experimental bottom culture beds with seeding densities of $1.5 \mathrm{~kg} \mathrm{~m}^{-2}$ (Site A), and $3.5 \mathrm{~kg} \mathrm{~m}^{-2}$ (Site B) were established $\left(56^{\circ} 40.1^{\prime} \mathrm{N}, 08^{\circ} 44.0^{\prime}\right.$ to 45.5' E) in March to May 2007 by MS 'Limfjorden' (Fig. 1A). The culture beds were $300 \times 300 \mathrm{~m}$ and $300 \mathrm{~m}$ apart. All blue mussel seed was harvested in Løgstør Broad, NE of the experimental cultures. Seeding densities were estimated from fishery reports to the fishery authorities and from observations of the fishery. During the transplantation process, 8 to 10 samples of 101 from each cargo were sampled in order to record the biomass of mussels in the catch. Shell lengths were also measured. One cargo of $135 \mathrm{t}$ (mean \pm SD shell length: $22.4 \pm$ $44.6 \mathrm{~mm}$ ) of mussel seed was transplanted to Site A in March 2007. Three cargos with a total of $315 \mathrm{t}$ (mean shell length: $23.5 \pm 7.4 \mathrm{~mm}$ in March and $26.4 \pm 5.3 \mathrm{~mm}$ in May) 
were transplanted to Site B from early March to early May.

In June and August 2007, 5 frame samples of $1 \mathrm{~m}^{2}$ were collected by a SCUBA diver at 3 stations at Sites A and B, respectively. Blue mussel densities, biomass density and shell length $(\mathrm{n}=200)$ were measured. At site A, blue mussel biomass density was also monitored at 1 station $(\mathrm{n}=5)$ in April 2007, $40 \mathrm{~d}$ after the transplantation, in order to test whether the transplanted biomass density of mussels corresponded to estimated biomass density from data on ship cargos of seed mussels. In May 2007, Site B was sampled by dredge, and shell lengths were measured $(\mathrm{n}=225)$.

All sampling was conducted on mussels transplanted between March and April 2007. The ratio between the production and the initial biomass $(P / B)$ in a bottom culture during a production period can be measured based on growth of individual mussels or growth of the population. The $P / B$ estimated on individual growth in relation to biomass of individual blue mussels ( $P / B$-ind) corresponds to $P / B$ estimated for the population in relation to the biomass of the population ( $P / B$-pop), subtracted a loss due to mortality in the population. P/B-pop multiplied by seeding density estimates the amount of harvestable blue mussels. P/B-pop from April to August was calculated as biomass production ([biomass end - biomass $\left._{\text {start }}\right] /$ biomass $_{\text {start }}$ ) in relation to initial biomass density in April.

Given the uniform size of the blue mussels, the relation between shell length $(\mathrm{cm})$ and wet weight (g) was calculated as the relation between mean shell length and mean wet weight (WW). The relation was described by the power function: $\mathrm{WW}=0.049 L^{3.51}$ $\left(\mathrm{R}^{2}=0.97, \mathrm{p}<0.0001\right)$. The average $P / B$-ind in April to August was calculated as $\left(\mathrm{WW}_{\text {August }}-\mathrm{WW}_{\text {April }}\right) /$ $\mathrm{WW}_{\text {Aprill }}$, where $\mathrm{WW}_{\text {April }}$ and $\mathrm{WW}_{\text {August }}$ are the average wet weights $(\mathrm{g})$ of individual blue mussels in April and August, respectively. Loss of production due to mortality was estimated as the difference between $P / B$-ind and $P / B$-pop.

\section{Model of impacted area}

Production of blue mussels in bottom culture includes collecting seed from natural blue mussel beds and harvesting full-grown mussels. Both processes include dredging. The total impacted area per harvest unit, when producing blue mussels in bottom culture $\left(A_{\text {cult }}\right)$, can be calculated as the sum of the area used for seed collection $(S)$ and the area used for bottom culture $(B)$, divided by the weight of the commercial harvest $(H)$ :

$$
A_{\text {cult }}\left(\mathrm{m}^{2} \mathrm{~kg}^{-1}\right)=\frac{S+B}{H}=\frac{d+f_{\text {seed }}}{0.67 f_{\text {seed }} d\left(1+P / B^{-p o p}\right)}
$$

where $d$ is seeding density $\left(\mathrm{kg} \mathrm{m}^{-2}\right)$ at the bottom culture, $f_{\text {seed }}$ is mussel seed biomass density at the seed fishery site $\left(\mathrm{kg} \mathrm{m}^{-2}\right), P / B$-pop is the population production ratio, and 0.67 is the efficiency of the dredge (Eigaard et al. 2011).

The impacted area $\left(A_{\text {com }}\right)$ when fishing full-grown $(>4.5 \mathrm{~cm})$ blue mussels for commercial sale can be calculated as:

$$
A_{\text {com }}\left(\mathrm{m}^{2} \mathrm{~kg}^{-1}\right)=\frac{1}{0.67 f_{\text {com }}}
$$

where $f_{\text {com }}$ is the biomass density of blue mussels at the fishery site, and 0.67 is the efficiency of the dredge.

\section{Scenarios based on interviews with mussel producers}

In order to estimate the impacted area, when producing blue mussels in bottom culture and when fishing full-grown mussels, 3 fishermen from the local producer association were interviewed on production practices. The fishermen specified that on average for Limfjorden, $f_{\text {seed }}=5 \mathrm{~kg} \mathrm{~m}^{-2} ; d=2.5$ to $3 \mathrm{~kg} \mathrm{~m}^{-2}$; and $f_{\text {com }}=2.5 \mathrm{~kg} \mathrm{~m}^{-2}$. Based on this information and the model of impacted area, different scenarios were tested in the model as a function of $P: B$-pop and seeding density $(d)$.

\section{Statistical analysis}

Data were tested for normality of distribution and homogeneity of variances, and if these requirements were met, parametric tests were used; otherwise, non-parametric tests were used. For comparison of densities among the 4 stations at the commercial bottom culture, a parametric 1-way analysis of variance (ANOVA) and post hoc Tukey test were used. Difference in shell growth and CI between stations was tested by 1-way ANOVA or non-parametric KruskalWallis tests followed by post hoc Dunn's method. Differences between settled and transplanted mussels were tested in separate Kruskal-Wallis tests.

In the field experiment, separate 1-sample $t$-tests were used to test whether the biomass densities of blue mussels at Sites A and B in April, June and August were different from the estimated seeding density. 


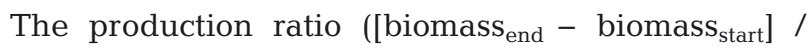
initial biomass) was tested by a 1-way ANOVA on ranks as a function of site. Changes in shell lengths were tested by linear regressions as a function of time. Differences in shell length as a function of time and site were tested by 2-way ANOVAs.

\section{RESULTS}

\section{Macrostructure of a commercial bottom culture}

A visual comparison of the transplantation tracks in the commercial bottom culture bed (Fig. 1A), the results from the side scan sonar mapping (Fig. 1B) and reports from the SCUBA diver in April 2009 confirmed that the tracks in which the blue mussels were transplanted to the commercial bottom culture in 2008 were clearly identifiable $1 \mathrm{yr}$ after transplantation. The results indicated that the transplantation practice on the commercial culture bed supported the formation of a robust bed structure.

\section{Growth in commercial bottom culture}

In April 2009, 1 yr after transplantation, a significant difference was observed in density between stations (1-way ANOVA, $F=10.53, \mathrm{p}<0.001$ ). The density (mean $\pm \mathrm{SD}$ ) of blue mussels increased from the edge (Stn 1: $545 \pm 704$ ind. $\mathrm{m}^{-2}$ ) across the bed (Stn 2: $1225 \pm 426$ and Stn 3: $1348 \pm 1208$ ind. $\mathrm{m}^{-2}$ ) to the middle (Stn 4: $2175 \pm 1027$ ind. $\mathrm{m}^{-2}$ ). The increase was significant between Stns 1 and 4 and 2 and 4 (Tukey test Stn 1 versus $4, \mathrm{p}<0.001$; Stn 2 versus 4 , $\mathrm{p}=0.040$ ).

The growth in shell length of the transplanted mussels ranged from 1.1 to $2.2 \mathrm{~mm} \mathrm{mo}^{-1}$, and the growth of the settled mussels ranged from 2.5 to $3.5 \mathrm{~mm}$ $\mathrm{mo}^{-1}$. The tests of shell growth showed significant differences between stations (transplanted: KruskalWallis, $\mathrm{p}<0.001$; settled: 1-way ANOVA, $F=35.23$, $\mathrm{p}<0.001)$. However, the pairwise comparison showed no systematic difference in growth comparing stations positioned at the edge and the centre of the commercial bottom culture (Fig. 2). A Kruskal-Wallis test showed a significant difference in shell growth between transplanted and settled mussels $(\mathrm{p}<0.001)$. Mussels that settled after the transplantation had significantly higher growth compared to transplanted mussels (Fig. 2).

The mean CI $( \pm \mathrm{SD})$ of the transplanted blue mussels ranged from $3.8 \pm 1.0$ to $5.2 \pm 0.9 \mathrm{mg} \mathrm{cm}^{-3}$, with sig- nificant differences between stations (Kruskal-Wallis test, $\mathrm{p}<0.001$; Fig. 3). Pairwise comparison of stations showed that CI was significantly higher at Stn 1 compared to Stns 2, 3 and 4 (Dunn's method $\mathrm{p}<0.05$ ).

\section{Production as a function of seeding density in experimental bottom cultures}

The biomass density of blue mussels was sampled at Site A, $40 \mathrm{~d}$ after transplantation in 2007. The mean biomass density $( \pm \mathrm{SD})$ was $1.76 \pm 1.31 \mathrm{~kg} \mathrm{~m}^{-2}$ and was not significantly different from the estimated seeding density (1-sample $t$-test, $\mathrm{p}=0.68)$, indicating that the transplanted biomass density corresponded to the estimated biomass density from data on ship cargos of seed mussels $\left(1.5 \mathrm{~kg} \mathrm{~m}^{-2}\right)$.

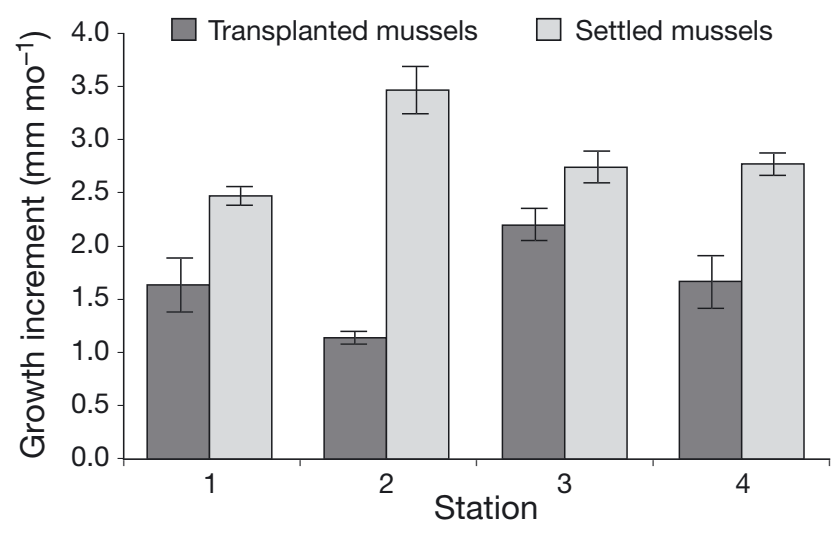

Fig. 2. Mytilus edulis. Mean shell length growth $( \pm \mathrm{SD})$ for blue mussels transplanted to a commercial bottom culture in April to June 2008 and for mussels settled in the culture bed after transplantation. The result of a pairwise comparison (Duncan method) of shell growth of transplanted mussels shows that Stn $3>\operatorname{Stn} 1=\operatorname{Stn} 2=\operatorname{Stn} 4$ and for settled mussels, $\operatorname{Stn} 2>\operatorname{Stn} 3=\operatorname{Stn} 4>\operatorname{Stn} 1$

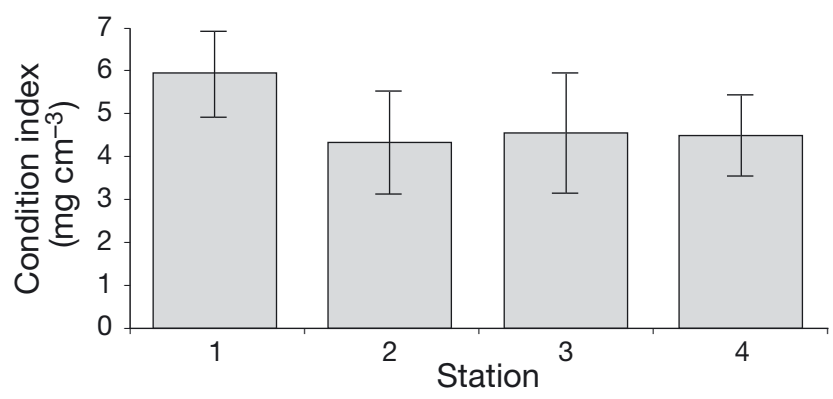

Fig. 3. Mytilus edulis. Mean condition index $( \pm \mathrm{SD})$ of blue mussels transplanted to a commercial bottom culture in April to June 2008. The result of the pairwise comparison (Duncan method) of shell growth of transplanted mussels shows that $\operatorname{Stn} 1>\operatorname{Stn} 2=\operatorname{Stn} 3=\operatorname{Stn} 4$ 
At Site A, the biomass density increased to $2.52 \mathrm{~kg}$ $\mathrm{m}^{-2}$ in June (Fig. 4), which was not significantly different from the estimated seeding density (1-sample $t$-test, $\mathrm{p}=0.26$ ). In August, the biomass density was $3.10 \mathrm{~kg} \mathrm{~m}^{-2}$, which was significantly different from the seeding density $(1$-sample $t$-test, $\mathrm{p}<0.05)$. At Site $B$, the biomass densities increased to $5.69 \mathrm{~kg}$ $\mathrm{m}^{-2}$ in June and $6.69 \mathrm{~kg} \mathrm{~m}^{-2}$ in August 2007. In both months, the biomass densities had increased significantly (1-sample $t$-test, June $\mathrm{p}=0.02$; August $\mathrm{p}=$ 0.03). $P / B$-pop from April to August 2007 corresponded to 1.1 and 1.0 at Sites $A$ and $B$, respectively, and was not significantly different between sites (1-way ANOVA on ranks, site: $\mathrm{p}=0.901$ ). The mean $( \pm \mathrm{SD}) P / B$-pop for the 2 sites was $1.0 \pm 1.7$.

At both sites, shell length increased significantly (Fig. 5). At Site $A$, the mean shell length $( \pm \mathrm{SD})$ increased from $22.4 \pm 4.7 \mathrm{~mm}$ in March to $39.9 \pm$ $5.2 \mathrm{~mm}$ in August 2007. At Site B, the mean shell length increased from $23.5 \pm 7.4 \mathrm{~mm}$ in March to $38.2 \pm 4.8 \mathrm{~mm}$ in August 2007. At the 2 sites, the shell growth rate of the transplanted mussels was 3.4 and $3.1 \mathrm{~mm} \mathrm{mo}^{-1}$, respectively, independent of seeding density. A significant interaction was observed between sites (A, B) and time (April, June, August; 2 -way ANOVA, $F=10.1, p=0.003)$, and the shell lengths were significantly larger at Site A compared to Site B in June, whereas no differences were observed in April and August 2007.

$P / B$-ind estimated as production of individual blue mussels from April to August 2007 were 2.5 and 2.0 at Sites $A$ and $B$, and $P / B$-pop constituted 40 and $50 \%$ of the individual production, respectively, indicating that 60 to $50 \%$ of the production was lost due to mortality.

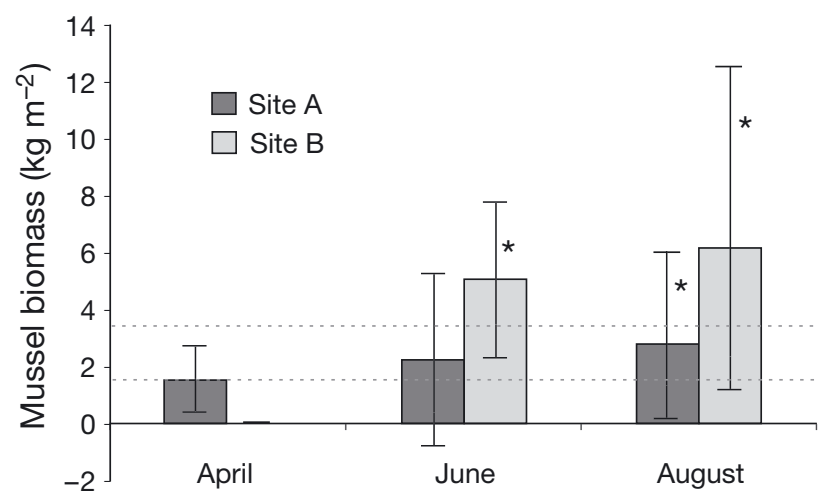

Fig. 4. Mytilus edulis. Mean biomass density $( \pm \mathrm{SD})$ of blue mussels transplanted to experimental beds (Sites A and B) in June and August 2009. Initial mussel biomass density at Sites A and B was 1.5 and $3.5 \mathrm{~kg} \mathrm{~m}^{-2}$, respectively, as indicated by horizontal lines. Biomass densities were tested against initial seeding density; ${ }^{*} \mathrm{p}<0.05$

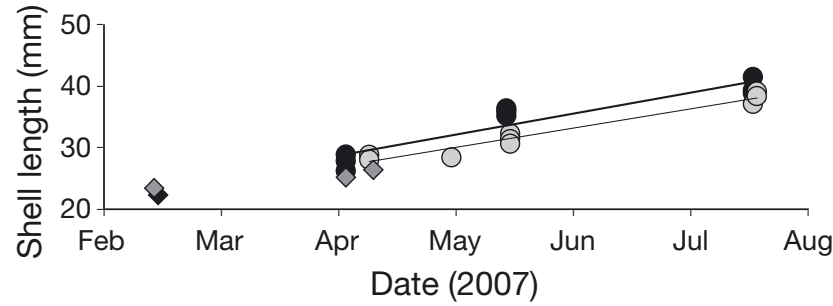

Fig. 5. Mytilus edulis. Shell length as a function of time when transplanted $(\bullet)$ and in experimental blue mussel beds (O) and at Site A (black) and Site B (grey). Linear regressions (Site A: $\mathrm{R}^{2}=0.87, \mathrm{p}<0.001$; Site B: $\mathrm{R}^{2}=0.95, \mathrm{p}<$ 0.001 ) showed that the growth rates measured as slopes were 3.4 and $3.1 \mathrm{~mm} \mathrm{mo}^{-1}$ at Sites $\mathrm{A}$ and $\mathrm{B}$, respectively

\section{Estimate of impacted area}

The area impacted by production of blue mussels in bottom culture $\left(A_{\text {cult }}\right)$ and the area impacted by dredging full-grown blue mussels from natural mussel beds $\left(A_{\text {com }}\right)$ were modelled for different scenarios (Fig. 6). The model results showed that the fishery of full-grown blue mussels at a biomass density of $2.5 \mathrm{~kg} \mathrm{~m}^{-2}$ would impact $0.59 \mathrm{~m}^{2} \mathrm{~kg}^{-1}$ (large grey arrow in Fig. 6) corresponding to a production in bottom culture with $P / B$-pop of 0.5 . At $P / B$-pop of 1.0 , the impacted area would be $0.44 \mathrm{~m}^{2} \mathrm{~kg}^{-1}$ (large black

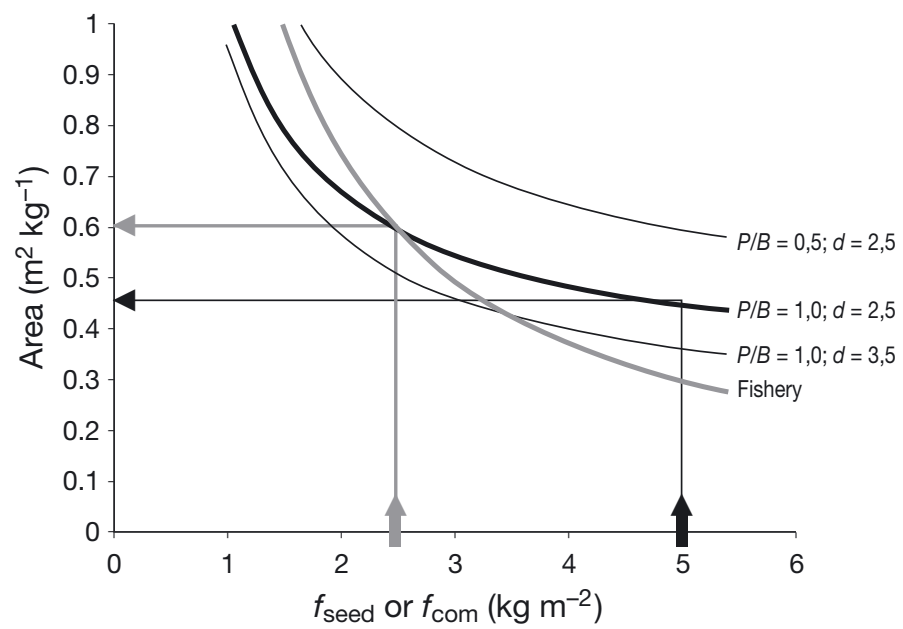

Fig. 6. Mytilus edulis. Model simulation of the impacted area when producing blue mussels in bottom culture or dredging of full-grown mussels. The impacted area in bottom culture was simulated based on a constant efficiency of the mussel dredge $(E=0.67)$, a population production:biomass density ratio $(P / B)$ of 0.5 or 1.0 and a seeding density $(d)$ of 2.5 or $3.5 \mathrm{~kg} \mathrm{~m}^{-2}$. The fishery (light gray line) was simulated based on a constant efficiency of the dredge $(E=0.67)$ and the mussel density at the fishery site $\left(f_{\text {com }}\right)$ (for further details see 'Materials and methods' and 'Results'). The small black arrow indicates the present production practice in relation to the seed fishery $\left(f_{\text {seed }}=5 \mathrm{~kg} \mathrm{~m}^{-2}\right)$, and the large black arrow points to the impacted area at a seeding density at $2.5 \mathrm{~kg} \mathrm{~m}^{-2}$ and a $P / B$ of 1.0 . The small gray arrow indicates the present production practice in relation to the fishery of full-grown mussels $\left(f_{\mathrm{com}}=2.5 \mathrm{~kg} \mathrm{~m}^{-2}\right)$, and the large gray arrow points to the corresponding impacted area 
arrow in Fig. 6). The scenarios revealed that the area impacted by bottom culture was smaller than the area dredged in the fishery of full-grown blue mussels if the seeding density at the bottom culture bed was larger than the present practice $\left(>2.5 \mathrm{~kg} \mathrm{~m}^{-2}\right)$, or if $P / B$-pop was larger than 0.5 (Fig. 6).

\section{DISCUSSION}

\section{Macrostructure of commercial bottom culture}

Our study of bottom culture showed that the mussel industry can transplant mussel seed of a predefined biomass density with high precision in order to establish robust bottom cultures that are not affected by wave- or current-induced transport. In 2009, the macrostructure of the culture bed was similar to the original transplantation tracks established the previous year. Blue mussels can be assumed to aggregate within the tracks (van de Koppel et al. 2005, 2008, Christensen et al. 2012), but not at a scale that changes the macrostructure of the tracks. Using a model, van de Koppel et al. (2005, 2008) demonstrated that self-organised spatial heterogeneity of blue mussels improves productivity compared to a completely homogeneous bed of blue mussels at the same density. We thus conclude that the mussel industry has developed adequate techniques to enable the establishment of blue mussel bottom cultures.

\section{Growth conditions in bottom culture}

In commercial bottom culture, growth in shell length was 1.1 to $3.5 \mathrm{~mm} \mathrm{mo}^{-1}$, with no systematic difference between the edge and the more central part of the culture. In the experimental bottom cultures established with a seeding density of 1.5 and $3.5 \mathrm{~kg} \mathrm{~m}^{-2}$, shell growth was estimated to be 3.4 and $3.1 \mathrm{~mm} \mathrm{mo}^{-1}$, respectively. The results from the commercial and the experimental bottom cultures indicated that these densities of mussels did not adversely affect shell growth. The estimated shell growth rates in bottom cultures are in the same range as those in natural mussel beds in Limfjorden (Kristensen \& Lassen 1997, Dolmer 1998, Christensen et al. 2012) and other eutrophic Danish estuaries (Petersen et al. 1997). It appears that the present procedure for transplanting blue mussels in tracks or long beds provides sufficient heterogeneity to avoid a decline in growth across the culture bed.
Investigations of the physical regime in Limfjord in relation to transport of seston to a mussel culture indicated that the water column switched between stratification due to a thermocline and mixing due to wind forcing, whereas turbulence due to currents was of minor importance (Wiles et al. 2006). Recorded chl a concentration in the area (Markager et al. 2006) should support high specific growth rates (Clausen \& Riisgård 1996) of suspended mussels, whereas blue mussels located on the sea bed may be limited due to food depletion in the boundary layer (Fréchette \& Bourget 1985a,b, Fréchette et al. 1989, Butman et al. 1994, Saurel et al. 2007) and during stratification (Møhlenberg 1995, Dolmer 2000). The CI is a function of dry weight of blue mussels. The specific growth is reported to be up to $9.5 \% \mathrm{~d}^{-1}$ (Clausen \& Riisgård 1996), and the CI will then reflect food conditions in the weeks before sampling. The CI of mussels in the commercial mussel culture was higher at the edge of the culture bed than within it, indicating that food availability was a limiting factor in the weeks before sampling. The CI was in the same range as reported for blue mussels of approximately similar sizes on natural mussel beds in May to June (Clausen \& Riisgård 1996). CI increases during the period of energy storage and gametogenesis, and decreases with the main spawning event (Gosling 2003). During the field campaign, only a few spawning mussels were observed, indicating that the main spawning event had not yet taken place. Thus, the relatively high CI in the commercial bottom culture is most likely due to the fact that the mussels had not yet spawned. The growth in shell length accumulates effects of food conditions during the life time of the bivalve, and shell length is then a function of food conditions over the long term. In relation to food limitation across the bottom culture, shell growth showed no effect, whereas an increased CI was observed at the edge. Periods of low wind mixing may result in food limitation during short periods (days, weeks) that can be monitored in the CI in the central part of the bottom culture. Factors other than food limitation may cause a reduced CI in the central part of the bottom culture (Gosling 2003). The hydraulic conditions can be assumed to be identical at the 4 stations, and differences in salinity or temperature may not explain the observed patterns. An increased density of predators in the central part of a bottom culture may cause a reduced CI. Interactions with predators (e.g. Carsinus maenas) reduce growth of blue mussels due to disturbance of filtration activity (Frandsen \& Dolmer 2002) or due to increased aggregation of the mussels (Christensen et al. 2012), which may increase food competition in the mussel bed and reduce CI. 
During the last 2 to $3 \mathrm{yr}$, Danish blue mussel producers have reported a low quality of blue mussels in bottom culture. Self-regulation implemented by the fishery ensures no harvest of the natural populations and bottom culture if the meat content (proportion of meat in a mussel when cooked) is $<14 \%$. This regulation has, at times, terminated the harvest of blue mussels due to low quality.

\section{$P / B$ ratios}

$P / B$-pop from April to August in the experimental bottom culture at Sites A and B was 1.0, and no difference was observed between sites. A seeding density up to $3.5 \mathrm{~kg} \mathrm{~m}^{-2}$ may therefore be recommended to the mussel industry. The measured $P / B$-pop corresponded to a ratio between seed and harvested biomass of 1:2. In bottom cultures of commercial value, Kristensen \& Lassen (1997) calculated that ratios between seeded biomass and harvestable biomass ranged from 1:0.3 to 1:0.9. Danish mussel producers have reported that due to reduced growth rates and low meat content of blue mussels in bottom culture over the last few years, the production time in bottom culture may have increased to several years before the mussels have attained a quality for harvest. In the Dutch Wadden Sea, Dankers (1987) and Kamermans \& Smaal (2002) reported a ratio of $1: 1$ and 1:1.5, respectively. Hence, the production estimated from our study is equal to or slightly higher than previously reported from Limfjorden and other areas.

Comparison of $P / B$-ind and $P / B$-pop indicated that 50 to $60 \%$ of the growth production is lost due to mortality. Loss of production from bottom cultures due to predation and other factors is well documented (e.g. Kristensen \& Lassen 1997). Kristensen \& Lassen (1997) studied production of 4 bottom cultures in Limfjorden. One of the cultures never produced blue mussels of commercial value due to an invasion by the starfish Asterias rubens, which consumed and eliminated the mussel population.

\section{Management perspectives for reducing impacted area}

Production in bottom culture requires that the mussels are dredged twice (i.e. dredging of seed and dredging of full-grown mussels for sale). The impacted areas when producing blue mussels with the 2 different methods were modelled based on the production parameters measured in the present study, the efficiency of the mussel dredge and information from the fishery on production practices for bottom culture production, and in the dredging fishery of full-grown blue mussels. In the model, a constant efficiency of the mussel dredge (0.67) is assumed based on investigations at a single site at blue mussel densities of $2.5 \mathrm{~kg}$ $\mathrm{m}^{-2}$ (Eigaard et al. 2011). In 2011, mussel producers implemented the mussel dredge used in the present model. The simulations indicated that the impacted area when producing in bottom culture was smaller than the dredged area of full-grown blue mussels if the seeding density was larger than in the present practice $\left(>2.5 \mathrm{~kg} \mathrm{~m}^{-2}\right)$ or if $P / B$-pop were larger than 0.5 . Hence, in our study, the bottom culture site with the lower seeding density (Site A) affected a larger area $\left(A_{\text {cult }}=0.64 \mathrm{~m}^{2} \mathrm{~kg}^{-1}\right)$ than dredging of full-grown mussels $\left(A_{\text {com }}=0.59 \mathrm{~m}^{2} \mathrm{~kg}^{-1}\right)$, whereas the bottom culture site with the higher seeding density (Site $B$ ) affected a smaller area $\left(A_{\text {cult }}=0.36 \mathrm{~m}^{2} \mathrm{~kg}^{-1}\right)$. This calculation assumed that the seed transplanted to Sites A and $\mathrm{B}$ was fished from a biomass density of $5 \mathrm{~kg} \mathrm{~m}^{-2}$. Moreover, the areas affected by the production of blue mussels in bottom culture can be reduced further by using seed produced on suspended collectors (Kamermans et al. 2002, 2009, Christensen et al. 2012), although the suspended cultures may also affect both pelagic and benthic habitats (McKindsey et al. 2011).

\section{Planning of bottom culture production}

Limfjorden is the most important area for the exploitation of blue mussels in Denmark (Kristensen \& Lassen 1997, Dolmer \& Frandsen 2002). According to the landing statistics registered by the Danish Ministry of Food, Agriculture and Fishery, the annual landings of blue mussels from Danish waters amounts to 25 to $35 \mathrm{kt}$ including 5 to $10 \mathrm{kt}$ produced in bottom culture (www.fd-statweb.fd.dk/landingsrapport). The statistics do not include the fishery for seed. Our study demonstrated that a shift from dredging fullgrown blue mussels from natural mussel beds to production of blue mussels in bottom culture in a eutrophic micro-tidal area can reduce the bottom area impacted by the production. The ecosystem impact of bottom culture production is reduced further if the transplantation exports blue mussels originating from (1) areas with high densities of mussels with a low growth rate or even with high mortality rate due to food limitation, and (2) areas with a high frequency of events of oxygen depletion and mass mortality. The production would then exploit a resource that, if left untouched, would partly disappear. The transplantations move extracted nutrients accu- 
mulated in blue mussel biomass (Gren et al. 2009) to new areas, where the blue mussels will continue extracting nutrients and improve transparency of the water by filtering seston until harvest, by which the nutrients are exported from the ecosystem. Eutrophication and reduced transparency in the water column are key issues in the management plans for Natura 2000 and WFD in Limfjorden. Bottom culture planned in accordance to conservation targets will intensify the blue mussel production in robust habitats, leaving more sensitive habitats to be permanently closed to mussel dredging, conserving the benthic flora and fauna in these areas. In order to implement the EU legislation (Natura 2000, MSFD, WFD) production of mussels by dredging seed from high-density beds and transplanting it to bottom culture may be a production method that can reduce the impacted area in relation to a dredge fishery on natural populations.

From a producer point of view, improvements of (1) reduced mortality due to predation from e.g. crabs and starfish and (2) food conditions in relation to seston concentration and transport of seston to the sea bed can significantly increase the production in bottom culture and reduce the impacted area in relation to production. Future development of the bottom culture production could focus on transplantations to more shallow-water areas in eutrophic estuaries where chl a concentrations often are higher and salinity is lower, which may reduce the density of starfish and thereby loss of mussel biomass due to predation (Rasmussen 1973). In relation to conservation objectives, development of bottom culture in eutrophic, shallow waters may pose a trade-off between different conservation targets, e.g. distribution of eelgrass Zostera marina due to potential overlap in the area affected by blue mussel culturing and the distribution of $Z$. marina. A spatial planning approach of blue mussel production in bottom culture is therefore central in order to optimize blue mussel production and ecosystem services and to minimize negative effects on conservation objectives. Therefore, further research should focus on developing a method to identify suitable areas for bottom culture which includes benefits for production, ecological and social interests.

Acknowledgements. This work was supported by The Danish Ministry of Food, Agriculture and Fisheries EFF contract 3745-10-n-0008 the Danish Scientific Council for Independent Research, Natural Sciences, MARINVA project no. 09066004, the Danish Council for Strategic Research, MUMIHUS project no. 09-066983, MARBIOSHELL project no. 2101-07-0084, and the EU-funded project COEXIST no. KBBE-3-245178-COEXIST. Thanks also to P. Nielsen, University of Copenhagen, and D. Tørring, Danish Shellfish
Centre, for practical help and comments on the manuscript, J. Støttrup for comments on the manuscript, O. Poulsen on the MS 'Limfjorden' and the staff onboard RVs 'Havmusen' and 'Per Sand Kristensen' for data and valuable comments.

\section{LITERATURE CITED}

Atkinson PW, Maclean IMD, Clark NA (2010) Impacts of shellfisheries and nutrient inputs on waterbird communities in the Wash, England. J Appl Ecol 47:191-199

Bayne BL (1976) Marine mussels: their ecology and physiology. International Biological Programme 10. Cambridge University Press, Cambridge

> Beadman HA, Kaiser MJ, Galanidi M, Shucksmith R, Willows RI (2004) Changes in species richness with stocking density of marine bivalves. J Appl Ecol 41:464-475

Blondel P (2009) The handbook of side scan sonar. Praxis Publishing Ltd, Chichester

> Butman CA, Fréchette M, Geyer WR, Starczak VR (1994) Flume experiments on food-supply to the blue mussel Mytilus edulis L. as a function of boundary-layer flow. Limnol Oceanogr 39:1755-1768

Christensen HT, Dolmer P, Petersen JK, Tørring D (2012) Comparative study of predatory responses in blue mussels (Mytilus edulis L.) produced in suspended long line cultures or collected from natural bottom mussel beds. Helgol Mar Res 66:1-9

Clausen I, Riisgård HU (1996) Growth, filtration and respiration in the mussel Mytilus edulis: no evidence for physiological regulation of the filter-pump to nutritional needs. Mar Ecol Prog Ser 141:37-45

> Collie JS, Hall SJ, Kaiser MJ, Poiner IR (2000) A quantitative analysis of fishing impacts on shelf-sea benthos. J Anim Ecol 69:785-798

Cranford PJ, Strain PM, Dowd M, Hargrave BT, Grant J, Archambault MC (2007) Influence of mussel aquaculture on nitrogen dynamics in a nutrient enriched coastal bay. Mar Ecol Prog Ser 347:61-78

Dankers N (1987) Some ecological effects of the mussel culture in the Dutch Wadden Sea. In: Tougaard S, Asbirk S (eds) Proc 5th Int Wadden Sea Symp, 29 September-3 October 1986. The National Forest and Nature Agency and The Museum of Fisheries and Shipping, Esbjerg, p 201-213

$>$ Dankers N, Zuidema DR (1995) The role of the mussel (Mytilus edulis L.) and mussel culture in the Dutch Wadden Sea. Estuaries 18:71-80

Dolmer P (1998) Seasonal and spatial variability in growth of Mytilus edulis L. in a brackish sound: comparisons of individual mussel growth and growth of size classes. Fish Res 34:17-26

> Dolmer P (2000) Feeding activity of mussels Mytilus edulis related to near-bed currents and phytoplankton biomass. J Sea Res 44:221-231

Dolmer P (2002) Mussel dredging: impact on epifauna in Limfjorden, Denmark. J Shellfish Res 21:529-537

> Dolmer P, Frandsen R (2002) Evaluation of the Danish mussel fishery: suggestions for an ecosystem management approach. Helgol Mar Res 56:13-20

> Dolmer P, Kristensen T, Christiansen ML, Petersen MF, Kristensen PS, Hoffmann E (2001) Short-term impact of blue mussel dredging (Mytilus edulis L.) on a benthic community. Hydrobiologia 465:115-127

> Dumbauld BR, Ruesink JL, Rumrill SS (2009) The ecological 
role of bivalve shellfish aquaculture in the estuarine environment: a review with application to oyster and clam culture in West Coast (USA) estuaries. Aquaculture 290:196-223

Eigaard O, Frandsen RP, Andersen B, Jensen KM and others (2011) Udvikling af skånsomt redskab til fiskeri af blåmuslinger. Technical University of Denmark, Charlottenlund (with English summary)

Frandsen RP, Dolmer P (2002) Effects of substrate type on growth and mortality of blue mussels (Mytilus edulis) exposed to the predator Carcinus maenas. Mar Biol 141: 253-262

- Fréchette M, Bourget E (1985a) Energy flow between the pelagic and benthic zones: factors controlling particulate organic matter available to an intertidal mussel bed. Can J Fish Aquat Sci 42:1158-1165

Fréchette M, Bourget E (1985b) Food-limited growth of Mytilus edulis L. in relation to the benthic boundary layer. Can J Fish Aquat Sci 42:1166-1170

Fréchette M, Butman CA, Geyer WR (1989) The importance of boundary-layer flows in supplying phytoplankton to the benthic suspension feeder, Mytilus edulis L. Limnol Oceanogr 34:19-36

Gosling E (2003) Bivalve molluscs-biology, ecology and culture. Blackwell, London

Gren IM, Lindahl O, Lindqvist M (2009) Values of mussel farming for combating eutrophication: an application to the Baltic Sea. Ecol Eng 35:935-945

Jennings S, Kaiser M (1998) The effects of fishing on marine ecosystems. Adv Mar Biol 34:201-352

Kaiser MJ, Clarke KR, Hinz H, Austen MCV, Somerfield PJ, Karakassis I (2006) Global analysis of response and recovery of benthic biota to fishing. Mar Ecol Prog Ser 311:1-14

Kamermans P, Smaal AC (2002) Mussel culture and cockle fisheries in the Netherlands: finding a balance between economy and ecology. J Shellfish Res 21:509-517

Kamermans P, Brummelhuis E, Smaal A (2002) Use of spat collectors to enhance supply of seed for bottom culture of blue mussels (Mytilus edulis) in the Netherlands. World Aquac 33:12-15

Kamermans P, Blankendaal M, Perdon J (2009) Predation of shore crabs (Carcinus maenas L.) and starfish (Asterias rubens L.) on blue mussel (Mytilus edulis L.) seed from wild sources and spat collectors. Aquaculture 290:256-262

- Kristensen PS, Lassen H (1997) The production of relaid blue mussels (Mytilus edulis L.) in a Danish fjord. ICES J Mar Sci 54:854-865

Lucas A, Beninger PG (1985) The use of physological condition indices in marine bivalve aquaculture. Aquaculture 44:187-200

Markager S, Storm LM, Stedmon CA (2006) Limfjordens miljøtilstand 1985 til 2003. Sammenhæng mellem næringsstoftilførsler, klima og hydrografi belyst ved hjælp af empiriske modeller. Report no 577. DMU, (with English summary)

McKindsey CW, Archambault P, Callier MD, Olivier F (2011) Influence of suspended and off-bottom mussel culture on the sea bottom and benthic habitats: a review. Can J Zool 89:622-646

Møhlenberg F (1995) Regulating mechanisms of phytoplankton growth and biomass in a shallow estuary. Ophelia 42 : 239-256

Editorial responsibility: Megan La Peyre,

Baton Rouge, Louisiana, USA
Neckles HA, Short FT, Barker S, Kopp BS (2005) Disturbance of eelgrass Zostera marina by commercial mussel Mytilus edulis harvesting in Maine: dragging impacts and habitat recovery. Mar Ecol Prog Ser 285:57-73

Okamura B (1986) Group living and the effects of spatial position in aggregations of Mytilus edulis. Oecologia 69: 341-347

Petersen JK, Schou O, Thor P (1997) In situ growth of the ascidian Ciona intestinalis (L.) and the blue mussel Mytilus edulis in an eelgrass meadow. J Exp Mar Biol Ecol 218:1-11

> Petersen JK, Bougrier S, Smaal AC, Garen P, Robert P, Larsen JEN, Brummelhuis E (2004) Intercalibration of mussel Mytilus edulis clearance rate measurements. Mar Ecol Prog Ser 267:187-194

Rasmussen E (1973) Systematics and ecology of the Isefjord marine fauna (Denmark). Ophelia 11:1-495

> Riisgård HU, Lundgreen K, Larsen PS (2012) Field data and growth model for mussels Mytilus edulis in Danish waters. Mar Biol Res 8:683-700

Saurel C, Gascoigne JC, Palmer MR, Kaiser MJ (2007) In situ mussel feeding behaviour in relation to multiple environmental factors: regulation through food concentration and tidal conditions. Limnol Oceanogr 52:1919-1929

Seed R (1976) Ecology. In: Bayne BL (ed) Marine mussels, their ecology and physiology. Cambridge University Press, Cambridge, p 13-65

> Smaal AC (2002) European mussel cultivation along the Atlantic coast: production status, problems and perspectives. Hydrobiologia 484:89-98

Smaal AC, Wijsman JWM, van Stralen MR (2010) Mussel culture and subtidal mussel stock management in the western Wadden Sea: Are exploitation and conservation compatible? Wadden Sea Ecosyst 26:145-150

Smith J, Shackley SE (2004) Effects of a commercial mussel Mytilus edulis lay on a sublittoral, soft sediment benthic community. Mar Ecol Prog Ser 282:185-191

Spencer BE (2002) Molluscan shellfish farming. Fishing News Books. Blackwell Science, Oxford

Suchanek TH (1981) The role of disturbance in the evolution of life history strategies in the intertidal mussels Mytilus edulis and Mytilus californianus. Oecologia 50: 143-152

Svane I, Ompi M (1993) Patch dynamics in beds of the blue mussel Mytilus edulis L.: effects of site, patch size, and position within a patch. Ophelia 37:187-202

van de Koppel J, Rietkerk M, Dankers N, Herman PMJ (2005) Scale-dependent feedback and regular spatial patterns in young mussel beds. Am Nat 165:E66-E77

van de Koppel J, Gascoigne JC, Theraulaz G, Rietkerk M, Mooij WM, Herman PMJ (2008) Experimental evidence for spatial self-organization and its emergent effects in mussel bed ecosystems. Science 322:739-742

Wiles PJ, van Duren LA, Häse C, Larsen J, Simpson JH (2006) Stratification and mixing in the Limfjord in relation to mussel culture. J Mar Syst 60:129-143

Yanick JF, Heath JW, Heath DD (2003) Survival and growth of local and transplanted blue mussels (Mytilus trossulus, Lamark). Aquacult Res 34:869-875

> Ysebaert T, Hart M, Herman PMJ (2009) Impact of bottom and suspended cultures of mussels Mytilus spp. on the surrounding sedimentary environment and macrobenthic biodiversity. Helgol Mar Res 63:59-74

Submitted: June 12, 2012; Accepted: November 19, 2012 Proofs received from author(s): December 12, 2012 